\title{
Comparison of the Original and Parallel Forms of the Three Words-Three Shapes Test
}

\author{
$\ddot{U} c ̧$ Kelime- $\ddot{U} c ̧$ Şekil Testinin Orijinal ve Paralel Formlarının Karşılaştırılması \\ Üzerine Bir Çalışma
}

\author{
(1) Çiğgdem Kudiaki ${ }^{1}$, (1) Asli Aslan², (1) Dilem Dinç̧ \\ ${ }^{1}$ Cigdem Kudiaki Individual and Organizational Development Consultancy, Ankara, Turkey \\ ${ }^{2}$ Mersin University Faculty of Science and Letters, Department of Psychology, Mersin, Turkey \\ ${ }^{3}$ Cag University School of Vocational, Department of Psychology, Mersin, Turkey
}

\begin{abstract}
Objective: The Three Words-Three Shapes test is a moderately difficult memory and learning test, which is very suitable for use in clinical applications. It allows the evaluation of both verbal and non-verbal materials in the same modality. Because neuropsychological evaluations may be repeated with certain intervals to follow a patient's progress, in situations where the progress of particularly degenerative diseases (e.g., Alzheimer or Parkinson-type dementia, primary progressive aphasia) need to be followed up, a parallel form of the test must be employed. Although normative data can be found for the original form of the test, the absence of data about the equivalency of its parallel form reduces the reliability of the test. Therefore, the aims of this study were to obtain normative data on the parallel form and compare the data on the parallel and original forms.

Materials and Methods: One hundred seventy-nine participants aged 50 to 84 years with no neurologic or psychiatric disorders were included in the study. Pre-evaluations of potential participants were performed using the Standardized Mini-Mental State Examination and Geriatric Depression Scale, and the individuals who scored above the cut-off points set for Turkey were included in the study.

Results: The average scores for the original and parallel forms of the test were found to have good agreement when they were applied with two-week intervals. According to the results of the correlation analysis, the correlation between incidental recall, acquisition and delayed recall subtests were significant. For the results that indicated no significant correlation for the copying and recognition subtests, separate charts of score frequencies are presented.
\end{abstract}

Conclusion: The observed values indicate that both forms of the three words-three shapes test can be reliably employed in parallel.

Keywords: Three Words-Three Shapes test, neuropsychological test, Alzheimer, elderly

Öz

Amaç: Üç Kelime-Üç Şekil testi, klinik uygulamalarda kullanmaya uygun bir bellek ve öğrenme testidir. Sözel ve sözel olmayan materyalleri aynı yöntemle değerlendirmeye izin verir. Özellikle dejeneratif hastalıklarda (Alzheimer veya Parkinson tipi demans, primer ilerleyici afazi vb.) ilerlemenin takip edilmesi gerektiği durumlarda, bir hastada belirli aralıklarla nöropsikolojik değerlendirmeler tekrar edilebileceği için, testin paralel formu da bulunmalıdır. Testin asıl formu için normatif veriler bulunmasına rağmen, paralel formunun eşdeğerliği hakkında veri bulunmaması testin güvenilirliğini azaltmaktadır. Bu nedenle bu çalışmanın amacı hem paralel form için norm veriler elde etmek hem de paralel ve orijinal formlardan elde edilen verileri karşılaştırmaktır.

Gereç ve Yöntem: Bu çalışmaya herhangi bir nörolojik ya da psikiyatrik hastalığı bulunmayan 50-84 yaşları arasında 179 kişi gönüllü olarak katılmıştır. Katılımcıların ön değerlendirmeleri, Standardize Mini-Mental Test ve Geriatrik Depresyon Ölçeği kullanılarak yapılmıştır ve Türkiye için belirlenen sınır değerlerin üzerinde puan alan kişiler çalışma kapsamına alınmıştır.

Bulgular: Orijinal ve paralel formlardan elde edilen ortalama skorlar, testler iki haftalık aralıklarla uygulandığında birbirine oldukça yakın bulunmuştur. Yapılan korelasyon analizi sonuçlarına göre, tesadüfi hatırlama, edinim ve gecikmiş geri çă̆ırma alt testleri arasında anlamlı korelasyon bulunmuştur. Aralarında anlamlı korelasyon bulunmayan kopyalama ve tanıma alt testlerine ait sonuçlar için skorların sıklık grafikleri ayrıca verilmiştir.

Sonuç: Gözlenen değerler, Üç Kelime-Üç Şekil testinin her iki formunun da paralel olarak güvenilir bir şekilde kullanılabileceğini göstermektedir.

Anahtar Kelimeler: Üç Kelime-Üç Şekil testi, nöropsikolojik test, Alzheimer, yaşlı

Address for Correspondence/Yazıșma Adresi: Dilem Dinç MD, Cag University School of Vocational, Department of Psychology, Mersin, Turkey

E-mail: dilemdinc@gmail.com ORCID ID: orcid.org/0000-0002-2042-3735

Received/Gelis Tarihi: 16.10.2017 Accepted/Kabul Tarihi: 07.02.2018

Presented in: This study presented in XI. European Conference on Social and Bebavioral Sciences at 02.09.2016.

${ }^{\circ}$ Copyright 2018 by Turkish Neurological Society

Turkish Journal of Neurology published by Galenos Publishing House. 


\section{Introduction}

An important component of neuropsychologic evaluations is the assessment of memory problems. Memory, which helps us store information and use it for adaptive purposes, is affected by many neurologic and psychiatric conditions (1). One of the most frequently cited reasons for applying neuropsychologic evaluations is detecting memory problems. There are many neuropsychologic tests for detecting these types of problems. Some of those are global screening tests [e.g., the Mini-Mental State Examination (MMSE), the Blessed Dementia Scale] and some are extensive tests on memory and learning, such as the Wechsler Memory Scale-3 (WMS-3) (2), the Rey Auditory Verbal Learning test (3), the California Verbal Learning test (4), the Rey-Osterrieth Complex Figure test (5), and Öktem Verbal Memory Process test (6). Detecting memory loss and learning may be difficult because the global screening tests evaluate memory and learning rather briefly, whereas longer extensive tests are more difficult for less educated patients with mild or moderate conditions. The Three Words-Three Shapes (hereby abbreviated as 3W3S) test, which was developed by Weintraub and Mesulam (7), is a short and quick memory and learning test, suitable for bed-side evaluations of various clinical conditions. Weintraub et al. (8) listed the distinguishing characteristics of the test as follows: First, most memory tests confound material (verbal vs. non-verbal) with modality (auditory vs. visual). For example, verbal memory is most often tested in the auditory modality with oral word lists or stories, and nonverbal memory is tested in the visual modality by reproduction of geometric designs or picture recognition. In order to keep the modality consistent, words and shapes are presented as both visual stimuli in the $3 \mathrm{~W} 3 \mathrm{~S}$ test. Secondly, it was required that all stimuli be copied prior to assessing memory to ensure that there were no primary writing or drawing deficits that could affect subsequent recall performance. A third innovation was to have an incidental encoding condition. Thus, participants were not forewarned to remember the stimuli as they copied them and spontaneous recall was tested immediately after copying. This condition assesses the amount of information that can be encoded without effort, a type of memory that has greater ecologic validity than memory based on rote learning. Following incidental recall of six items, a number of effortful encoding (i.e., rote learning) trials were presented to bring the participant to a criterion level before testing delayed recall. Delayed recall was then tested and compared with the recognition of the items in order to assess the specific contribution of retrieval versus retention failure to overall explicit memory. The difficulty level of the $3 \mathrm{~W} 3 \mathrm{~S}$ test can be evaluated as moderate (9). Therefore, it presents enough information on the nature of both learning and memory. It can also be easily applied to patients at the beginning and middle stages of dementia, even to those with low levels of education. Its suitability for bed-side evaluations makes the work of physicians easier. Weintraub et al. (9) noted that the $3 \mathrm{~W} 3 \mathrm{~S}$ test could distinguish patients with probable Alzheimer's disease from those with Korsakoff syndrome. Patients with probable Alzheimer's were the lowest scoring group among the three groups taking all their tests. Among those tests, the lowest scores were obtained in the incidental recall tests. The researchers stated that the incidental recall test score was critical in distinguishing memory deficits. Another study demonstrating the distinguishing characteristics of the test was undertaken by Weintraub et al. (8) to compare patients with primary progressive aphasia (PPA) and Alzheimer-type dementia (DAT) to control group and determine whether personal memory evaluations were affected by the modality (verbal vs. non-verbal) of the presented material. The results of that study showed that patients with PPA recalled words with greater difficulty than shapes, but the difficulty differential was lower for patients with DAT. The low scores of patients with PPA depended on the material, especially in the incidental learning phase. However, patients with DAT scored low on both words and shapes. Those observations indicated that the test provided discerning information on different neurodegenerative conditions. One of the goals of neuropsychological evaluations is to follow the progress of cognitive disorders. Depending on the progress, a need arises for parallel forms equivalent to the tests applied to the patients. In cases where equivalent forms are not used, repeatedly taking the same test will lead to learning effects (1). The goal of the present study was to implement an equivalent parallel form for use in patients who require follow-up with the $3 \mathrm{~W} 3 \mathrm{~S}$ test. The researchers of the present study had already developed a parallel form of the Weintraub et al. (9) $3 \mathrm{~W} 3 \mathrm{~S}$ test. This study was undertaken to establish its equivalency to the original test in the manner it was implemented in Turkey because a parallel form was needed for this test, which is frequently applied in clinical settings.

\section{Materials and Methods}

\section{Participants}

One hundred seventy-nine volunteer participants were randomly recruited from cities of the Mediterranean region, such as Adana, Hatay and Mersin. The participants were all aged 50 to 84 years [mean $(M)=59.65$, standard deviation $(S D)=7.55$ ]. Participants' education level varied from unschooled but literate, to 25 years of education $(\mathrm{M}=10.77, \mathrm{SD}=4.31)$.

All participants were selected according to the following criteria:

- Having a Standardized MMSE (SMMSE) (10, 11-in Turkish) score greater than 23 (for participants with more than 5 years of primary education) or greater than 16 (for participants with less than 5 years of primary education (12-in Turkish),

- Having a Geriatric Depression Scale (GDS) (13, 14-in Turkish) score lower than 14,

- Having no prior history of stroke, dementia, cerebrovascular anomalies, Parkinson's disease, multiple sclerosis, psychiatric conditions or any chronic medical conditions such as lung, liver, and kidney failure,

- Not using any medication that might affect test performance, such as anti-depressants, anti-psychotics, anxiolytics, antiepileptics for the treatment neurologic and/or psychiatric illnesses.

\section{Data Collection Tools}

As data collection tools, a personal information questionnaire, SMMSE and GDS forms, the $3 \mathrm{~W} 3 \mathrm{~S}$ original forms, verbal fluency tests based on animal and people's names, a number sequence, Weschler Memory Scale-Logical Memory subscale, and the 3 W3S parallel form were used. The personal information questionnaire was given to determine the demographic characteristics (such as age, level of education and profession) of the participant, their 
psychiatric or neurologic conditions, if any, and whether or not they had been using any medications.

- The GDS used in this study was developed by Yesavage et al. (15) and standardized exclusively for Turkish by Ertan et al. (14). It consisted of 30 items asking the participants whether they felt themselves ...during the last week. Each item received a "yes" or "no" answer.

- The classic MMSE test was developed by Folstein et al. (16) and the SMMSE test was developed by Molloy and Standish (10). The latter was standardized for use in Turkey by Güngen et al. (11). This test had two forms, one applied to participants with at least 5 years of primary school education and one applied to others with less than five years of education.

- The 3 W3S test original form employs two cards, papers, and a pencil. The first card contains $3 \mathrm{~W} 3 \mathrm{~S}$, the second card contains 10 words and 10 shapes, which include the correct words and shapes of the first card, along with others intended to confound the subject. The subject is asked to copy the word and shapes they saw on the first card and they were not forewarned about remembering them. The card and the paper is then removed and the person is immediately asked to write and draw all six stimuli on a blank piece of paper. This process assesses incidental recall and working memory. At this stage of incidental recall, each correct word or shape earns 4 points. Correct words or shapes in the correct positions (relative to others) are assigned 1 extra point each. For each stimulus (word or shape) the highest score is 5 , bringing the highest total to 15 . In the event a subject cannot recall at least five stimuli, the words and shapes are shown again, and the subject is tested again, up to four more times. In each repeat trial, the words and shapes are shown for 30 seconds and the subject is asked to recall them while the card is placed face down. The test is abandoned altogether if the subject is unsuccessful in the first and following 4 repeat trials. If the subject scores sufficient points, a delayed recall test is given 15 minutes later. After the delayed recall test, a recognition test is presented. The recognition test includes confounding words and shapes, along with the correct ones. In this test, the participant is asked to point to the words and shapes they saw before. The flow diagram of the test is as follows:

- 3W3S test parallel form consists of two different cards. The first card contains $3 \mathrm{~W} 3 \mathrm{~S}$. The second card contains 10 words and 10 shapes, including the correct ones on the first card. In the development of the parallel form, the three shapes from the parallel form by Weintraub et al. (9) were used, but the words on the two cards were changed for the adaptation to Turkish. The word changes were made by three faculty members of the psychology department with expertise in cognitive psychology. For the construction of the words, a list of 30 words were selected and appropriate words were then selected from this list. Each selected word was individually matched for frequency of occurrence in Turkish use, word length, and word meaning, with a word from the original $3 \mathrm{~W} 3 \mathrm{~S}$ test. The scoring of the parallel form was performed as in the original form. Directions and scoring cards were arranged to make them completely clear for the testgivers. The original form developed by Weintraub and Mesulam (7) had three delayed recall tests at 5, 15, and 30 minutes after the test, but in the form adapted for Turkey (17), only one delayed recall test at 15 minutes was retained for practical reasons. For that reason, it was decided that only one delayed recall test would also be used for parallel form. There was also only one delayed recall test given at 15 minutes in the Weintraub et al. (8) study.

\section{Application}

Test-givers took theoretical and practical training from faculty members who were experts in clinical or cognitive psychology. Each test-giver was evaluated after the training in order to ensure that they had gained the proper skills for giving the test and no mistakes would occur. Each participant was given the test twice with a two-week interval. The ordering was changed for both the original and parallel forms. A participant who was given the original form in the first week was given the parallel form in the second week. This order was changed for each participant randomly. The order for all of the tests was as follows:

The personal information questionnaire, SMMSE, GDS, 3W3S original/parallel form (copying and incidental recall tests), a number sequence consisting of 9 numbers, each of which had one extra digit more than the previous one, WMS logical memory test (A and B forms), 3W3S delayed recall test (parallel/original form).

The ordering of the original and parallel forms of $3 \mathrm{~W} 3 \mathrm{~S}$ were changed for each participant. Tests were applied in a room where the participant directly faced the test-giver and no other extraneous stimuli were present.

The approval was obtained from Rectorate of Mersin University's Clinical Researches Ethics Committee (file no: 15/237, date: 17.08 .2017$)$.

\section{Results}

Analyses were performed to compare the original form and parallel forms of $3 \mathrm{~W} 3 \mathrm{~S}$ with respect to each component of verbal and shape modalities. According to Pearson correlation analyses, there was a significant positive correlation between incidental recall trial scores of form $1(\bar{X}=12.12, S D=3.82)$ and form 2 $(\overline{\mathrm{X}}=11.79, \mathrm{SD}=4.07)$ for shapes $[\mathrm{r}(177)=0.57, \mathrm{p}<0.001]$. There was a significant positive correlation between incidental recall trial scores for form $1(\bar{x}=11.72, S D=4.32)$ and form $2(\bar{x}=12.07$, $\mathrm{SD}=4.69$ ) for words modality $[\mathrm{r}(177)=0.31, \mathrm{p}<0.001]$. There was a significant positive correlation between acquisition trial scores of form $1(\overline{\mathrm{X}}=13.90, \mathrm{SD}=1.79)$ and form $2(\overline{\mathrm{X}}=13.64, \mathrm{SD}=2.18)$ for shapes modality $[\mathrm{r}(174)=0.42, \mathrm{p}<0.001]$. There was a significant positive correlation between acquisition trial scores for form $1(\bar{X}=13.94, \mathrm{SD}=2.30)$ and form $2(\bar{X}=14.49, \mathrm{SD}=1.50)$ for words modality $[\mathrm{r}(174)=0.15, \mathrm{p}<0.001]$. There was a significant positive correlation between delayed recall trial scores for form 1 $(\bar{X}=13.48, S D=2.32)$ and form $2(\bar{X}=12.78, S D=2.94)$ for shapes modality $[\mathrm{r}(170)=0.45, \mathrm{p}<0.001]$. There was a significant positive correlation between delayed recall trial scores for form $1(\overline{\mathrm{X}}=12.37$, $\mathrm{SD}=3.95)$ and form $2(\overline{\mathrm{X}}=11.75, \mathrm{SD}=4.45)$ for words modality $[\mathrm{r}(178)=0.25, \mathrm{p}<0.001]$. However, no significant correlations were found for copying and recognition trials. The fact that almost all participants scored 5 may explain the absence of a correlation; there was no linear relationship. The score frequency charts for each word or shape are presented. The scores in those charts ranged from 0 to 5 . The score frequencies can be found in Figures 1, 2, 3, and 4. Arithmetic means and SDs of scores for each component of the verbal and shape modalities and Pearson correlation coefficients are shown in Table 1. 

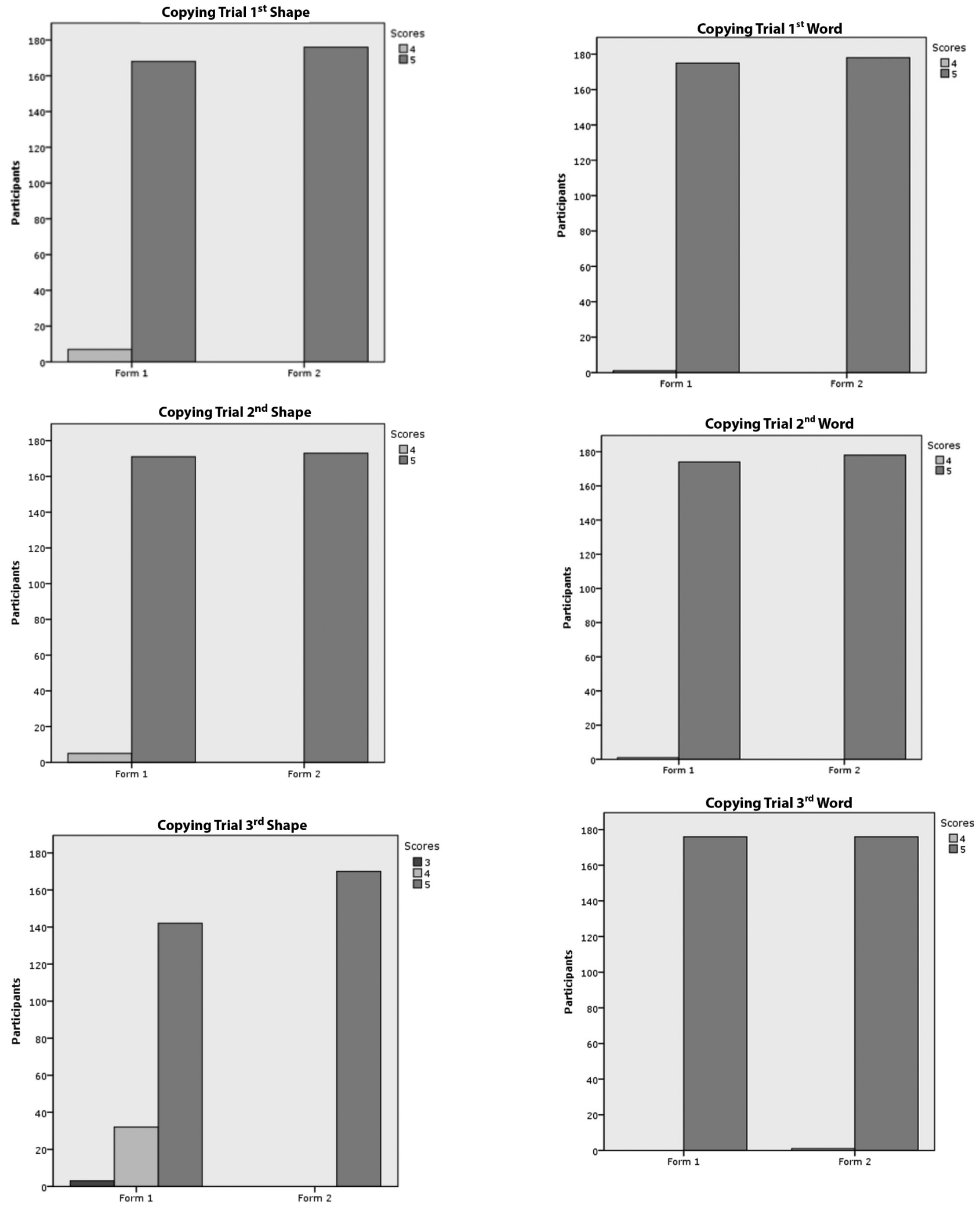

Figure 1. Score frequencies of copying trial (scores between 0-5) in for $1^{\text {st }}, 2^{\text {nd }}$, and $3^{\text {rd }}$ shapes both in the original and parallel forms
Figure 2. Score frequencies of copying trial (scoresbetween 0-5) for the $1^{\text {st }}, 2^{\text {nd }}$, and $3^{\text {rd }}$ words both in the original and parallel forms 

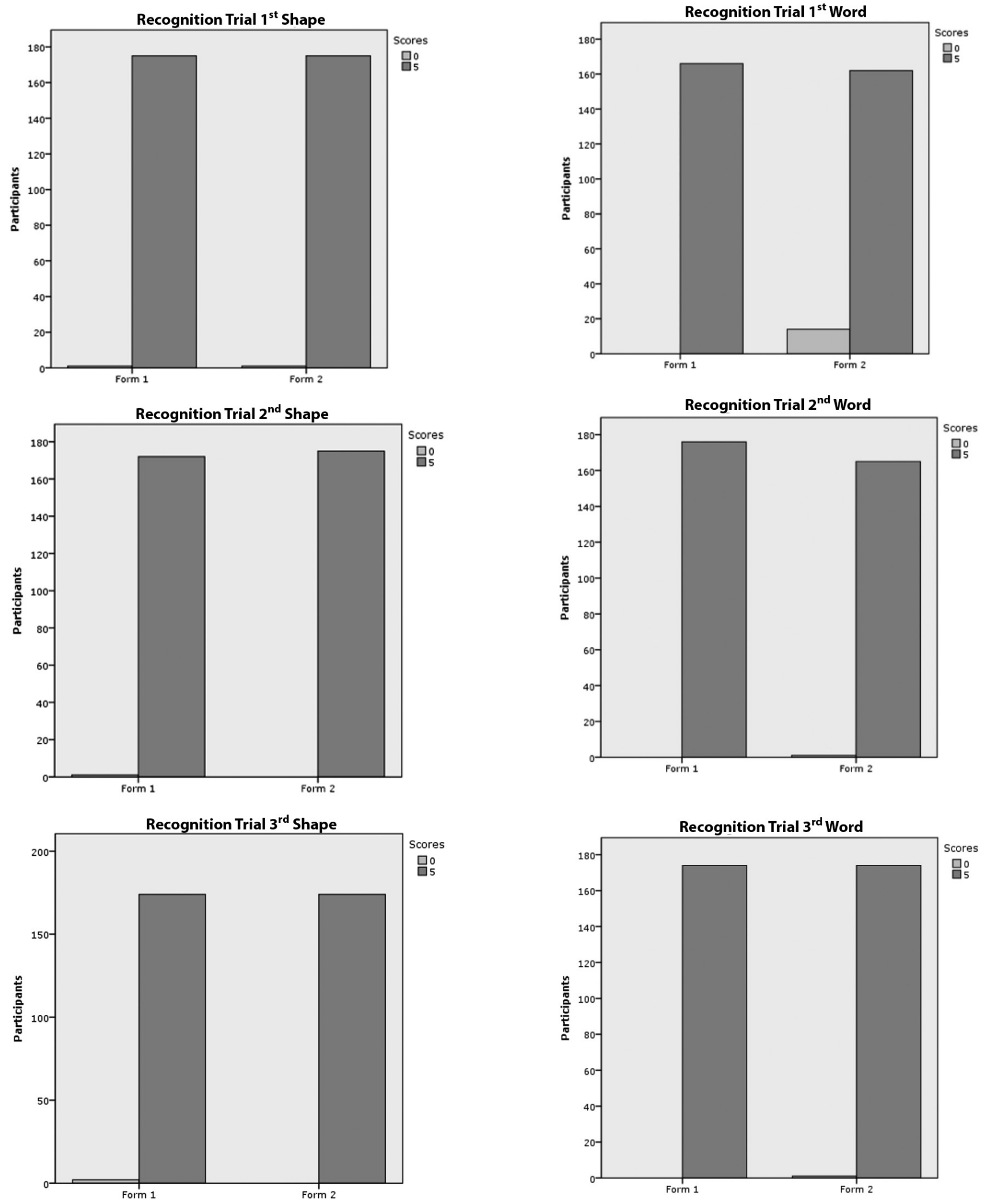

Figure 3. Score frequencies of recognition trial (scores between 0-5) for the $1^{\text {st }}, 2^{\text {nd }}$, and $3^{\text {rd }}$ shapes both in the original and parallel forms

Figure 4. Score frequencies of recognition trial (scores between 0-5) for the $1^{\text {st }}, 2^{\text {nd }}$, and $3^{\text {rd }}$ words both in the original and parallel 
Table 1. Summary of Pearson correlation analyses between form 1 and form 2

\begin{tabular}{|c|c|c|c|c|c|c|c|c|}
\hline & \multicolumn{3}{|c|}{ Original form (form 1) } & \multicolumn{5}{|c|}{ Parallel form (form 2) } \\
\hline & $\overline{\mathbf{x}}$ & SD & Range & $\overline{\mathbf{x}}$ & SD & Range & $\mathbf{r}$ & $\mathrm{p}$ \\
\hline \multicolumn{9}{|l|}{ Copy } \\
\hline Word & 14.98 & 0.13 & $14-15$ & 14.99 & 0.07 & $14-15$ & -0.00 & 0.91 \\
\hline \multicolumn{9}{|c|}{ Incidental recall } \\
\hline \multicolumn{9}{|l|}{ Acquisition } \\
\hline Shape & 13.90 & 1.79 & $7-15$ & 13.64 & 2.18 & $6-15$ & 0.57 & $<0.001^{*}$ \\
\hline Word & 13.94 & 2.30 & $5-15$ & 14.49 & 1.50 & $8-15$ & 0.15 & $<0.001^{*}$ \\
\hline Learning trails & 1.49 & .50 & $1-2$ & 1.48 & 0.50 & $1-2$ & - & - \\
\hline \multicolumn{9}{|l|}{ Recognition } \\
\hline Shape & 14.77 & 1.04 & $10-15$ & 15.00 & 0.00 & $15-15$ & - & - \\
\hline Word & 14.63 & 1.31 & $10-15$ & 14.45 & 1.56 & $10-15$ & 0.05 & 0.48 \\
\hline
\end{tabular}

\section{Discussion}

Being a moderately difficult memory and learning test, the $3 \mathrm{~W} 3 \mathrm{~S}$ test is very suitable for clinical applications, especially for Turkey, where the average level of education is still rather low. Having a parallel form, this test also allows a second application for following up the progress of neuro-degenerative conditions such as Alzheimer or, Parkinson's-type dementia, and PPA. In order to put the parallel form into proper use, establishing its equivalency to the original form is very important for the reliability of clinical utility. This study was undertaken for this purpose and the average scores were found to be very close for the subtests of both the original and the parallel forms. On the other hand, correlation analyses for the scores of two subtests (copying and recognition) showed no significant relationship; therefore, frequencies of all possible scores for words and shapes were examined and the results are presented in score frequency charts. The frequencies show that most participants scored the maximum points for the copying and recognition subtests and the reason for the absence of a correlation might be the low scores of a few participants.

\section{Conclusion}

In conclusion, both forms of the $3 \mathrm{~W} 3 \mathrm{~S}$ test are deemed to be usable for clinical applications in Turkey.

\section{Ethics}

Ethics Committee Approval: The approval was obtained from Rectorate of Mersin University's Clinical Researches Ethics Committee (file no: 15/237, date: 17.08.2017).

Informed Consent: Consent form was filled out by all participants.

Peer-review: Externally peer-reviewed.

\section{Authorship Contributions}

Surgical and Medical Practices: Not applied. Concept: Ç.K., A.A., Design: Ç.K., A.A., D.D., Data Collection or Processing: A.A., D.D., Analysis or Interpretation: A.A., D.D., Literature Search: Ç.K., A.A., Writing: Ç.K., A.A.

Conflict of Interest: No conflict of interest was declared by the authors.

Financial Disclosure: The authors declared that this study received no financial support.

\section{References}

1. Lezak MD, Howieson DB, Loring DW. Neuropsychological assessment. 4th ed. New York: Oxford University Press, 2004.

2. Wechsler D. Wechsler memory scale-III manual. San Antonio, TX: The Psychological Corporation, 1997.

3. Rey A. L'examen clinique en psychologie. Paris: Presses Universitaires de France, 1970.

4. Delis D, Kramer J, Kaplan E, Ober B. The California verbal learning test. New York: Psychological Corporation, 1987.

5. Osterreith P. Le test decopie d'une figure complexe. Archives de Psychologie 1944;30:206-356.

6. Öktem Tanör Ö. Öktem Sözel Bellek Süreçleri Testi (ÖKTEM SBST) El Kitabı. Birinci Baskı, Ankara, Türk Psikolog Derneği Yayınları, 2011.

7. Weintraub S, Mesulam MM. Mental state assessment of young and elderly adults in behavioural neurology. In: Mesulam MM (ed). Principles of behavioral neurology. 4th ed. Philadelphia: FA Davis, 1985:71-123.

8. Weintraub S, Rogalski E, Shaw E, et al. Verbal and nonverbal memory in primary progressive aphasia: The Three Words-Three Shapes Test. Behav Neurol 2013;26:67-76.

9. Weintraub S, Peavy GM, O'Connor MO, et al. Three words-three shapes: A clinical test of memory. J Clin Exp Neuropsychol 2000;22:267-278. 
10. Molloy DW, Standish TI. A guide to the standardized mini mental state examination. Int Psychogeriatr 1997;9(Suppl 1):87-94.

11. Güngen C, Ertan T, Eker E, Yasar R, Engin F. The Standardized Mini Mental State Examination in Turkish. In Proceedings of the 9th ed. Congress of The International Psychogeriatric Assossiation, 1999.

12. Ertan T, Eker E, Güngen C, et al. The standardized mini mental state examination for illiterate Turkish elderly population. In Proceedings of the 2nd ed. international symposium on neuropsychological and neuropsychological assessment of mental and behavioral disorders, 1999.

13. Brink TL, Yesavage JA, Lum O, Heersema PH, Adey M, Rose TL. Screening tests for geriatric depression. Clinical Gerontologist 1982;1:37-43.
14. Ertan T, Eker E, Sar V. Reliability and validity of the geriatric depression scale in Turkish elderly population. Arch Neuropsychiatry 1997;34:62-71.

15. Yesavage JA, Brink TL, Rose TL, et al. Development and validation of a geriatric depression screening scale: A preliminary report. J Psychiatr Res 1983;17:37-49.

16. Folstein MF, Folstein SE, McHugh PR. "Mini-mental state": a practical method for grading the cognitive state of patients for the clinician. J Psychiatr Res 1975;12:189-198.

17. Kudiaki C, Aslan A. The three words- three shapes test: Normative data for the Turkish elderly. Arch Clin Neuropsychol 2007;22:637-645. 